\title{
Changes in the Numbers of Cetaceans near the Pribilof Islands, Bering Sea, between 1975-78 and 1987-89
}

\author{
LARIANN BARETTA ${ }^{1,2}$ and GEORGE L. HUNT Jr. ${ }^{1,3}$
}

(Received 5 July 1993; accepted in revised form 18 April 1994)

\begin{abstract}
We compared the number of cetaceans seen during surveys of seabird distribution in the vicinity of the Pribilof Islands, Bering Sea, during two periods, 1975-78 (3867 km surveyed) and 1987-89 (6101 km surveyed). During the 1980s, we saw increased numbers of fin whales (Balaenoptera physalus) (0 to 66 individuals), minke whales (B. acutorostrata) (3 to 38 individuals), humpback whales (Megaptera novaeangliae) (0 to 24 individuals), killer whales (Orcinus orca) (5 to 58 individuals), and Dall's porpoises (Phocoenoides dalli) (101 to 241 individuals). It could not be determined whether these changes reflected changes in the numbers of these species in the Bering Sea, or simply local changes in their foraging or distribution patterns. Fin, humpback and minke whales were seen foraging in the vicinity of large flocks of birds that were eating euphausiids (Thysanoessa raschii and T. inermis).
\end{abstract}

Key words: Fin whale, minke whale, humpback whale, killer whale, Dall's porpoise, Balaenoptera physalus, Balaenoptera acutorostrata, Megaptera novaeangliae, Orcinus orca, Phocoenoides dalli, Bering Sea, whale foraging

RÉSUMÉ. On a comparé le nombre de cétacés aperçus durant des relevés de la répartition d'oiseaux marins dans le voisinage des îles Pribilof, dans la mer de Béring, durant deux périodes de trois ans, de 1975 à 1978 (3867 km de distance de relevés) et de 1987 à 1989 (6101 km de distance de relevés). Au cours des années 1980, on a aperçu un plus grand nombre de rorquals communs (Balaenoptera physalus) [de 0 à 66 individus], de petits rorquals (B. acutorostrata) [de 3 à 38 individus], de rorquals à bosse (Megaptera novaeangliae) [de 0 à 24 individus], d'épaulards (Orcinus orca) [de 5 à 58 individus] et de marsouins de Dall (Phocoenoides dalli) [de 101 à 241 individus]. On n'a pu déterminer si ces changements reflétaient une évolution du nombre de ces espèces dans la mer de Béring, ou simplement des modifications locales dans les schémas d'alimentation ou de répartition. On a aperçu des rorquals communs, des rorquals à bosse et des petits rorquals en train de se nourrir à proximité de grandes volées d'oiseaux qui se nourrissaient d'euphausiacés (Thysanoessa raschii et T. inermis).

Mots clés: rorqual commun, petit rorqual, rorqual à bosse, épaulard, marsouin de Dall, Balaenoptera physalus, Balaenoptera acutorostrata, Megaptera novoaeangliae, Orcinus orca, Phocoenoides dalli, mer de Béring, alimentation des baleines

Traduit pour la revue Arctic par Nésida Loyer.

\section{INTRODUCTION}

The distribution and abundance of cetaceans in the southeastern Bering Sea have been surveyed in recent years from ships and from the air (e.g., Frost et al., 1982; Leatherwood et al., 1983; Brueggeman et al., 1987). Only a few surveys have resulted in reports on the distribution and abundance of species near the Pribilof Islands (Frost et al., 1982; Leatherwood et al., 1983). None have reported repeated surveys at the same time of year in different years.

During marine bird surveys from 1975 to 1978 (Hunt et al., 1981) and from 1987 to 1989 near the Pribilof Islands, we recorded the occurrence of marine mammals. Although our surveys were not designed to study the distribution or abundance of marine mammals, marine mammals were recorded consistently as part of the marine environment used by birds. These records provide an index to changes in marine mammal use of the waters near the Pribilof Islands from the late 1970s to the late 1980s.
The Pribilof Islands were chosen as our study area because of the large numbers of seabirds that nest there (Sowls et al., 1978). The waters around these islands also support various cetaceans. Rice and Wolman (1971) and Braham et al. (1992) reported gray whales (Eschrichtius robustus) feeding in shallow inshore waters, and Leatherwood et al. (1983) reported sightings of fin (Balaenoptera physalus), minke (B. acutorostrata) and killer whales (Orcinus orca) near the Pribilofs in July 1982. In this paper, we compare observations of cetaceans near the Pribilof Islands between 1975 and 1978 with those made between 1987 and 1989, and we interpret our observations in light of past studies of the distribution and abundance of these species in the southeastern Bering Sea.

\section{METHODS}

Observations of marine mammals were recorded in the vicinity of the Pribilof Islands on six cruises between 1975 and

\footnotetext{
${ }^{1}$ Department of Ecology and Evolutionary Biology, University of California, Irvine, California 92717, U.S.A.

${ }^{2}$ Present address: 1539 C. Gustavo St., El Cajon, California 92019, U.S.A.

3 Reprint requests should be sent to G.L. Hunt Jr.

(C) The Arctic Institute of North America
} 
1989 (Figs. 1 to 6). Our surveys in the 1970s were designed to identify important foraging areas and flight lines for seabirds, and each line was surveyed once in a given year. In the 1980s, our surveys were designed to compare densities of seabirds foraging around St. Paul and St. George Islands. In 1987 and 1988, all transect lines were run twice, once without stopping for stations, and once with regularly spaced oceanographic stations. In 1987, about half of the lines were run twice in the same day, with runs on the other lines separated by a day or more, depending upon weather conditions. In 1988, all transect lines were run twice on the same day. In 1989, we duplicated some of the lines north of St. Paul Island that had been surveyed in the 1970s, and these lines were surveyed once. Other areas to the north and east of St. Paul Island and to the east and south of St. George Island were the sites of process studies, and lines were run repeatedly on the same day, as we attempted to determine the effects of tidal processes on seabird feeding.

Observations were made from the flying bridges of the SS Surveyor and SS Discoverer (eye height $21 \mathrm{~m}$ above sea surface, horizon 9.5 nautical miles, speed 10 to 15 knots) during the 1970s, and during the 1980s, from within the wheelhouse of the RV Alpha Helix (eye height $7.7 \mathrm{~m}$ above sea surface, horizon 5.7 nautical miles, speed 10.5 knots). All cetaceans observed along the cruise track were recorded, regardless of their distance from the ship. Binoculars ( $7 \times$ and $10 \times$ ) were used to search for and to identify animals to species. In no year did we deviate from the trackline to identify or enumerate cetaceans; cetaceans far from the trackline could not be identified to species. Identification to species was assigned only if a clear view of the flukes or dorsal profile was obtained.

From 1975 to 1978 , observations were made both by bird observers, who reported the sightings to the bridge watch, and by marine mammal observers assigned to the ship. Observations were recorded on data forms of the Marine Mammal Platforms of Opportunity Program (POP) for entry into the POP database maintained by the National Marine Mammal Laboratory (Consiglieri and Bouchet, 1981). Following our 1987-89 surveys, we requested POP data from cruises on which we had participated during the period 1975-78. From these data, we extracted records resulting from our observations in the 1970s that were obtained in the same areas surveyed in the 1980s. From 1987 to 1989 , all marine mammal observations were made and recorded into a microcomputer by the bird observers. One observer (G.L. Hunt) was present on most cruises in the 1970s and all cruises in the 1980s. Although observations on most cruises were made by individuals untrained in the survey of marine mammals, most observers were familiar with the identification of whales from encountering them on seabird or marine mammal surveys done elsewhere.

For the purpose of analysis, we divided our study area into four zones: Near Island, Shelf, Shelf Break and Deep Water. The Near Island zone included all surveys within $20 \mathrm{~km}$ of the islands. The Shelf zone included surveys on water farther than 20 $\mathrm{km}$ from the islands, and less than $200 \mathrm{~m}$ deep. The Shelf Break zone included waters between 200 and $1000 \mathrm{~m}$ deep, and the Deep Water zone included surveys on water over $1000 \mathrm{~m}$ deep. Counts from 1975 to 1978 were compared with those from 1987 to 1989 , using $\log$ likelihood ratio tests with the Williams (1976) correction. The null hypothesis for these tests was uniform abundance in the two decades. Expected frequencies were calculated by multiplying the total number of animals counted in the two decades by the proportional survey effort (measured in transect km) in each decade. For these tests, we did not try to account for resightings because we had no objective way to assess the number of times that an individual animal was seen.

Goodness of fit tests were conducted for all species/spatial subdivisions for which expected frequencies exceeded five individuals. Ten comparisons met this criterion. Because we conducted multiple unplanned tests, we used the Bonferroni procedure to adjust for a maximum familywise type I error rate of $p=0.05$. The critical value of the chi-square distribution for ten comparisons with one degree of freedom is 7.838 (Rohlf and Sokal, 1981:Table 15).

\section{RESULTS}

During the period 1975-78, we surveyed $3867 \mathrm{~km}$ of trackline and counted 116 cetaceans (Table 1, Figs. 1 to 3 ). During the period 1987-89, we covered $6101 \mathrm{~km}$ of trackline and counted 501 cetaceans (Figs. 4 to 6). For 1987 to 1989, sightings made on the outbound and inbound runs on a transect are shown on opposite sides of the tracklines in Figures 4 to 6 . In each year in the 1980s, we had on two occasions what were probably resightings of groups of fin whales. In 1988, we also had a probable recount of a minke whale to the east of St. Paul Island, and in 1989, there was a probable recount of a humpback whale to the northwest of St Paul Island. In 1989, there were probable multiple recounts of minke and possibly of fin whales to the east of St. George Island in an area where we were studying murres (Uria spp.) foraging on euphausiids over a shallow bank (Coyle etal., 1992). We were unable to identify a large number of whales during our cruises (e.g., 70 from 1987 to 1989).

The number of individuals seen per year by area and the rate of encounter $/ 100 \mathrm{~km}$ of trackline were significantly higher from 1987 to 1989 than from 1975 to 1978 for five species of cetaceans (Tables 1 and 2). The frequency of sightings of groups (regardless of the number of individuals present) was consistently higher in the 1980s than in the 1970s for virtually all cetacean species observed (Table 3). We cannot estimate the magnitude of the change in cetacean numbers because we did not obtain data suitable for computing densities. Fin whales were in groups of four or fewer, whereas killer whale group size varied up to twelve. Dall's porpoises (Phocoenoides dalli) were most often encountered in groups of three or less, but one group contained an estimated 26 individuals.

Our data suggest a differential use of various areas by the five cetacean species, although the relatively small sampling effort over the shelf break and over deep water makes it difficult to interpret cetacean use of these areas (Table 1). We saw fin and humpback whales (Megaptera novaeangliae) most frequently over shelf waters away from the islands, whereas minke whales were most common within $20 \mathrm{~km}$ of the islands in the 1980s. Fin, humpback and minke whales were observed foraging in close 
proximity to large flocks of seabirds (short-tailed shearwaters, Puffinus tenuirostris and thick-billed murres, Uria lomvia) that were known to be foraging on euphausiids (Thysanoessa raschii and T. inermis) in water less than $50 \mathrm{~m}$ deep (Coyle et al., 1992; Hunt et al., unpubl.). On 12 August 1989, we encountered six to

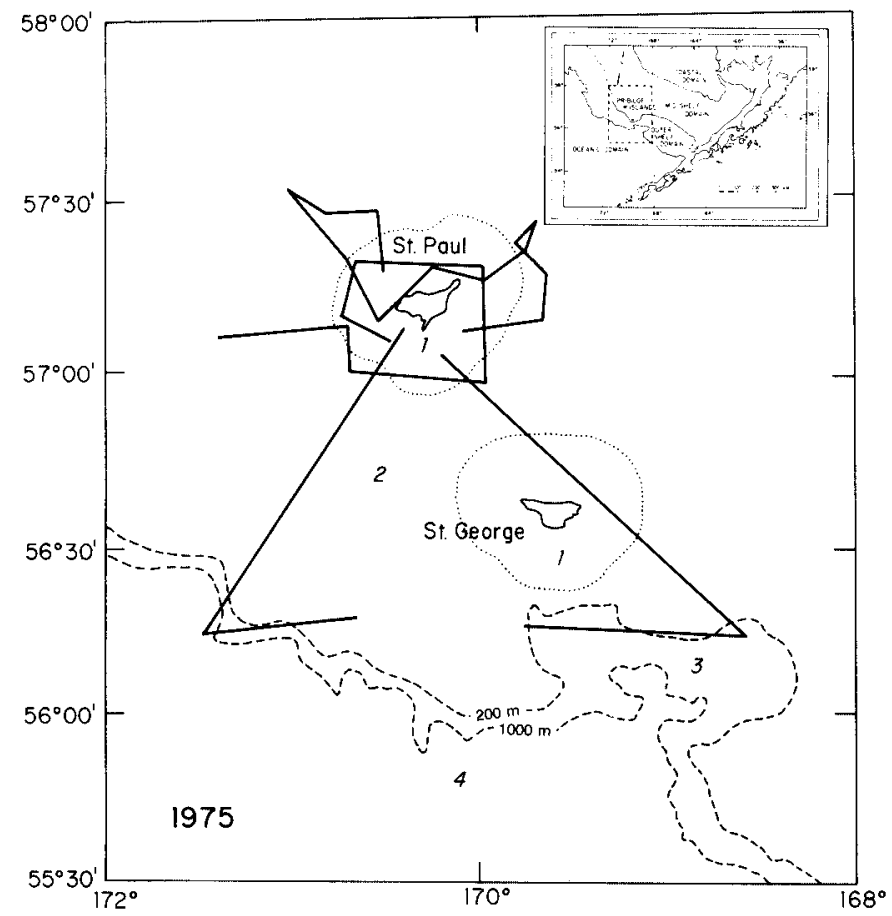

FIG. 1. Survey effort during 20-23 August 1975. For regions defined in the text, $1=$ near island, $2=$ shelf, $3=$ shelf break, $4=$ deep ocean. Tracklines shown were of daytime surveys. No whales were seen during our surveys in 1975.

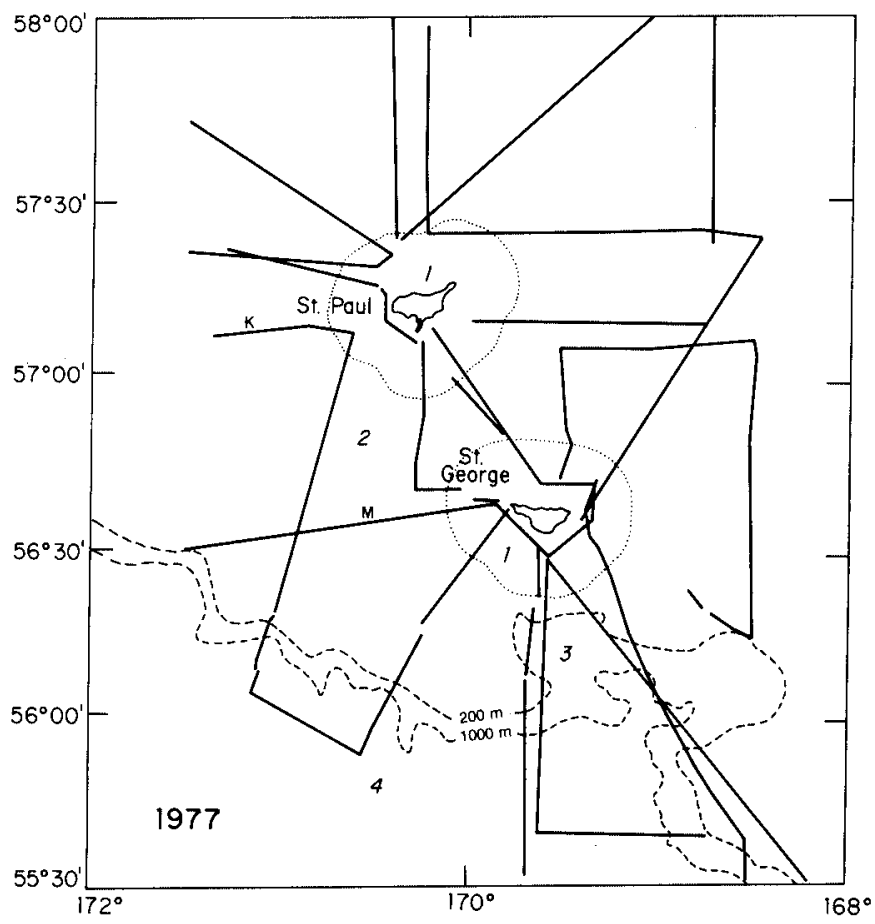

FIG. 2. Survey effort during 7-11 July and 1-5 August 1977. For keys to numbered regions, see Figure 1 caption. Tracklines shown were of daytime surveys. $\mathrm{K}=$ killer whale sighting, $\mathrm{M}=$ minke whale sighting. eight humpback and two fin whales in the vicinity of a flock of about 1500 foraging short-tailed shearwaters. The fin whales were surfacing around the edge of the shearwater flock. The humpback whales were breaching and spy-hopping initially, but as we approached, they shifted to making frequent short dives

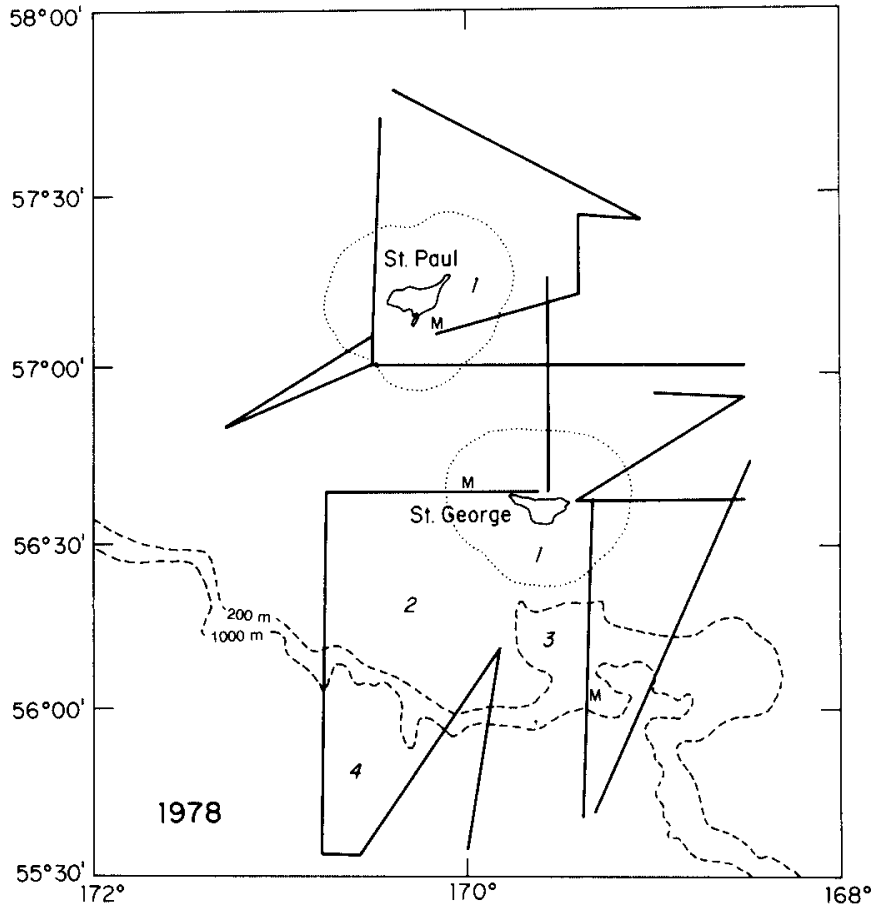

FIG. 3. Survey effort during 10-14 August 1978. For keys to numbered regions, see Figure 1 caption. Tracklines shown were daytime surveys. $\mathrm{M}=$ minke whale sighting.

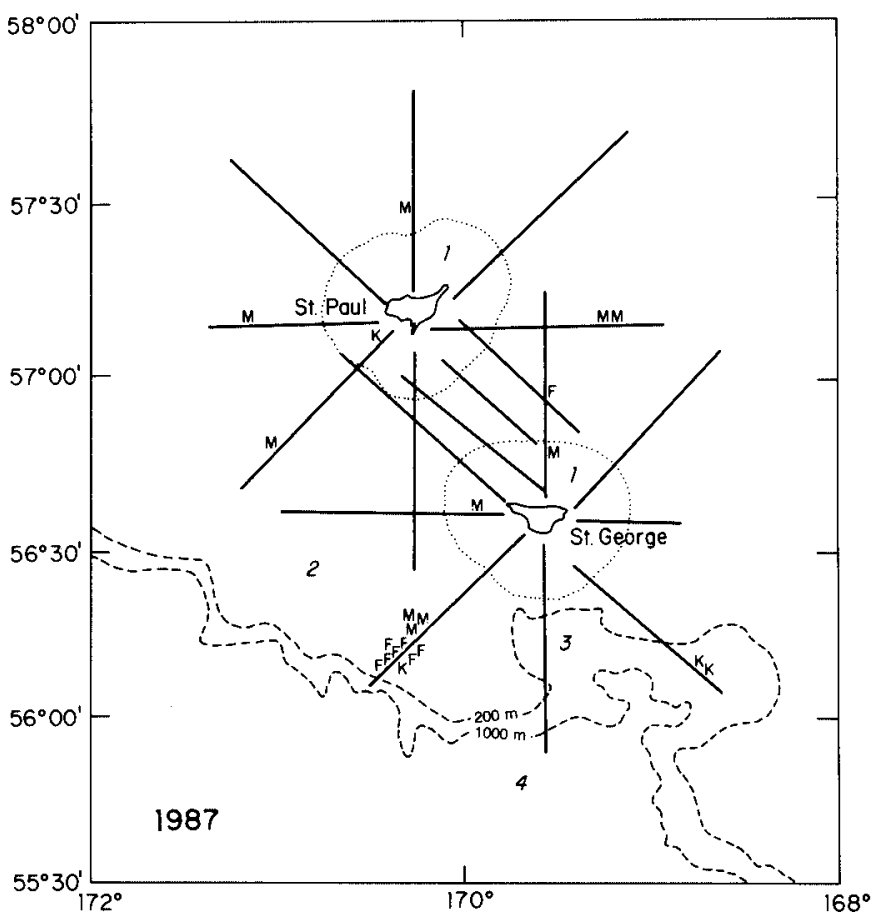

FIG. 4. Survey effort during 22 July-17 August 1987. For keys to numbered regions, see Figure 1 caption. Tracklines shown were daytime surveys. $F=$ fin whale sighting, $\mathrm{K}=$ killer whale sighting, $\mathrm{M}=$ minke whale sighting. 


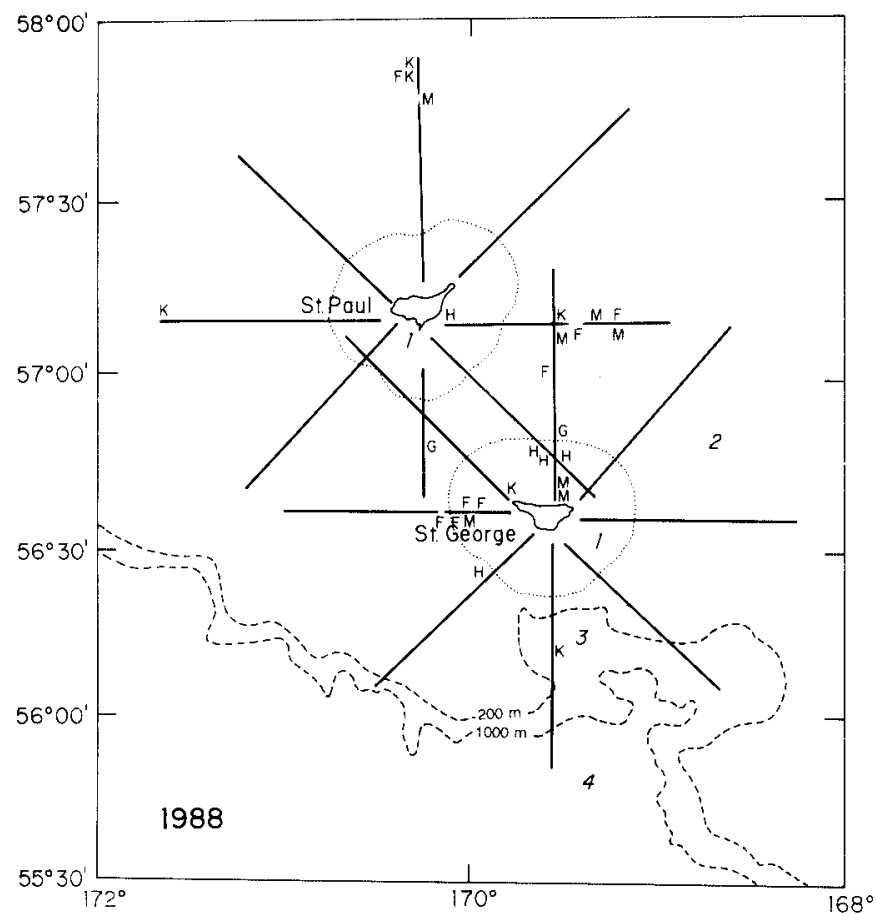

FIG. 5. Survey effort during 28 July-20 August 1988. For keys to numbered regions, see Figure 1 caption. Tracklines shown were daytime surveys. F = fin whale, $\mathrm{G}=$ gray whale, $\mathrm{H}=$ humpback whale, $\mathrm{K}=$ killer whale, $\mathrm{M}=$ minke whale.

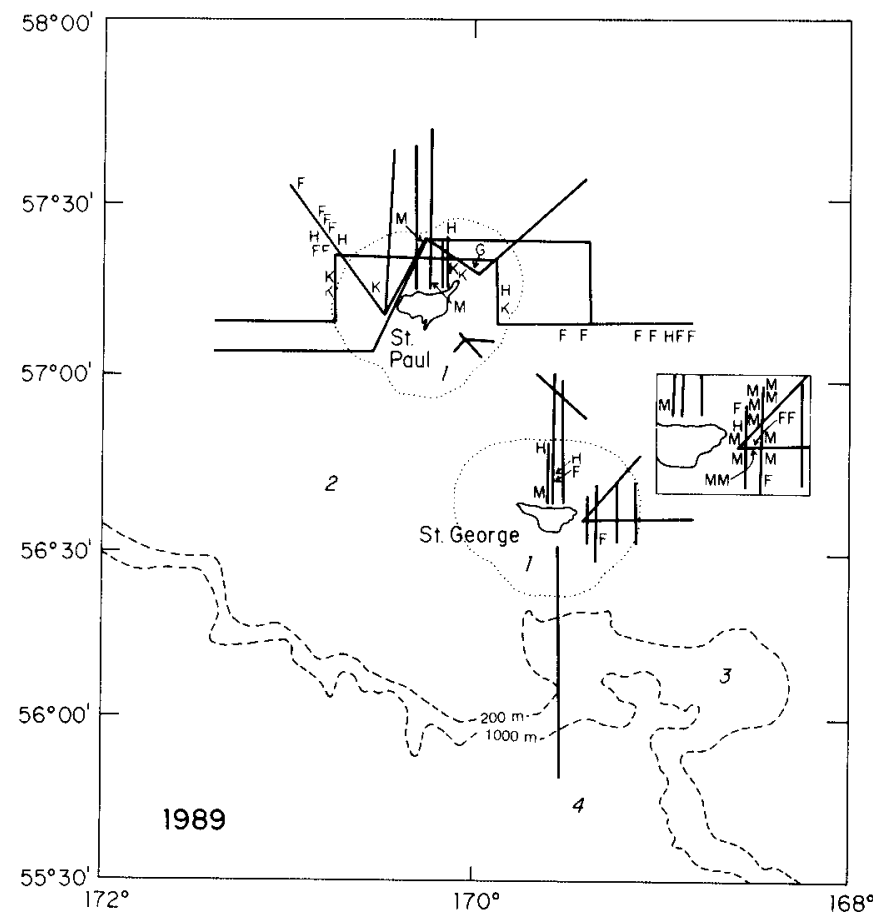

FIG. 6. Survey effort during 6-28 August 1989. For keys to numbered regions, see Figure 1 caption; for keys to cetacean species, see Figure 5 caption. Tracklines shown were daytime surveys. and movements at or just below the surface. Farther out on the same transect, we saw three fin and two humpback whales together.

\section{DISCUSSION}

The data from the two periods are not strictly comparable because we used different platforms, survey designs, and modes of recording observations. The 1975-78 observations were made from the flying bridge of large ships, which afforded clear views of the splashes or blows of surfacing marine mammals. The 1987-89 observations were made from within the pilot house of a much smaller ship, eye height was lower, and therefore, sighting efficiency and detection distance were compromised. These differences in platforms would be expected to bias the 1987-89 marine mammal sightings downward. Conversely, during the 1987-89 period, we managed our own database and are assured that all observations were recorded, whereas during the 1975-78 period, we depended on others to transfer our marine mammal observations to the National Marine Mammal Laboratory. We are confident that most, if not all, sightings of cetaceans were recorded during the 1970 s because sightings were rare, and they created much interest among the officers and crews of the ships. In the 1980s we concentrated much of our survey effort in areas where seabirds
TABLE 1. Numbers of cetaceans observed by area (see Figs. 1 to 6) near the Pribilof Islands in the periods 1975-78 and 1987-89. Figures in parentheses are the number of individuals seen $/ 100 \mathrm{~km}$ surveyed.

\begin{tabular}{|c|c|c|c|c|c|c|c|c|}
\hline & \multicolumn{2}{|c|}{$\begin{array}{c}\text { Near Island } \\
\text { (within } 20 \mathrm{~km} \text { ) }\end{array}$} & \multicolumn{2}{|c|}{$\begin{array}{c}\text { Shelf } \\
(<200 \mathrm{~m} \text { depth })\end{array}$} & \multicolumn{2}{|c|}{$\begin{array}{c}\text { Shelf Break } \\
(200-1000 \mathrm{~m} \text { depth })\end{array}$} & \multicolumn{2}{|c|}{$\begin{array}{c}\text { Deep Water } \\
(>1000 \mathrm{~m} \text { depth })\end{array}$} \\
\hline & $70 \mathrm{~s}$ & $80 \mathrm{~s}$ & $70 \mathrm{~s}$ & $80 \mathrm{~s}$ & $70 \mathrm{~s}$ & $80 \mathrm{~s}$ & $70 \mathrm{~s}$ & $80 \mathrm{~s}$ \\
\hline Kms surveyed & 885 & 2359 & 2215 & 3392 & 359 & 300 & 408 & 50 \\
\hline Fin whale & 0 & $\begin{array}{l}14 \\
(0.6)\end{array}$ & 6) & $\begin{array}{l}52 \\
(1.5)\end{array}$ & 0 & 0 & 0 & 0 \\
\hline Minke whale & $\begin{array}{l}1 \\
(0.1)\end{array}$ & $\begin{array}{l}20 \\
(0.9)\end{array}$ & $\begin{array}{l}2 \\
(0.1)\end{array}$ & $\begin{array}{l}18 \\
(0.5)\end{array}$ & 0 & 0 & 0 & 0 \\
\hline Humpback whale & 0 & $\begin{array}{l}6 \\
(0.3)\end{array}$ & 3) & $\begin{array}{l}18 \\
(0.5)\end{array}$ & 0 & 0 & 0 & 0 \\
\hline Gray whale & 0 & 1 & 0 & 2 & 0 & 0 & 0 & 0 \\
\hline Killer whale & 0 & $\begin{array}{l}15 \\
(0.2)\end{array}$ & $\begin{array}{l}5 \\
(0.2)\end{array}$ & $\begin{array}{l}28 \\
(0.8)\end{array}$ & 0 & $\begin{array}{l}15 \\
(5.0)\end{array}$ & 0 & 0 \\
\hline Unidentified whale & 0 & 26 & 0 & 38 & 0 & 6 & 0 & 0 \\
\hline Dall's porpoise & 0 & $\begin{array}{l}5 \\
(0.2)\end{array}$ & $\begin{array}{l}49 \\
(2.2)\end{array}$ & $\begin{array}{l}148 \\
(4.4)\end{array}$ & $\begin{array}{l}28 \\
(7.8)\end{array}$ & $\begin{array}{l}79 \\
(26.3)\end{array}$ & $\begin{array}{l}24 \\
(5.9)\end{array}$ & $\begin{array}{c}9 \\
(18.0)\end{array}$ \\
\hline Unidentified porpoise & se 0 & 0 & 6 & 1 & 1 & 0 & 0 & 0 \\
\hline TOTAL & $\begin{array}{c}1 \\
(0.1)\end{array}$ & $\begin{array}{l}87 \\
(3.7)\end{array}$ & $\begin{array}{ll}62 \\
7) & (2.8)\end{array}$ & $\begin{array}{l}305 \\
(9.0)\end{array}$ & $\begin{array}{l}29 \\
(8.1)\end{array}$ & $\begin{array}{l}100 \\
(33.3)\end{array}$ & $\begin{array}{l}24 \\
(5.9)\end{array}$ & $\begin{array}{c}9 \\
(18.0)\end{array}$ \\
\hline
\end{tabular}


TABLE 2. Results of G tests comparing changes in numbers of cetaceans seen in the 1970s and the 1980s near the Pribilof Islands.

\begin{tabular}{lcccc}
\hline \hline Species & Habitat & Trend & Gadj & $p<0.05$ \\
\hline Fin whale & Shelf & + & 51.77 & YES \\
Minke whale & Near Island & + & 7.14 & NO \\
Minke whale & Shelf & + & 8.59 & YES \\
Humpback whale & Shelf & + & 17.60 & YES \\
Killer whale & Shelf & + & 9.22 & YES \\
Killer whale & Shelf Break & + & 22.86 & YES \\
Unid. whale & Near Island & + & 16.27 & YES \\
Unid. whale & Shelf & + & 37.70 & YES \\
Dall's porpoise & Shelf & + & 18.72 & YES \\
Dall's porpoise & Shelf Break & + & 35.23 & YES \\
\hline \hline
\end{tabular}

TABLE 3. Frequency of sightings (regardless of group size) of cetaceans by year.

\begin{tabular}{lrrrrrr}
\hline \hline & 1975 & 1977 & 1978 & 1987 & 1988 & 1989 \\
\hline Kms surveyed & 613 & 2220 & 1034 & 2250 & 2009 & 1842 \\
Fin whale & & & & & & \\
Minke whale & 0 & 0 & 0 & 8 & 8 & 17 \\
Humpback whale & 0 & 0 & 0 & 0 & 5 & 14 \\
Gray whale & 0 & 0 & 0 & 0 & 2 & 1 \\
Killer whale & 0 & 1 & 0 & 4 & 6 & 6 \\
Unidentified whale & 0 & 0 & 0 & 5 & 22 & 16 \\
Dall's porpoise & 0 & 8 & 6 & 21 & 32 & 6 \\
Unknown porpoise & 0 & 2 & 0 & 0 & 1 & 0 \\
\hline \hline
\end{tabular}

were foraging on euphausiids - areas to which whales were also attracted. The probable multiple resightings of minke whales close to St. George Island did not result in the assessment of a statistically positive trend; however, the differences in the numbers of fin whales seen between the two decades was robust (Table 2). Thus, we believe that the reported differences in sighting rates between the two periods reflect real increases in the numbers of cetaceans present. We cannot evaluate the impact of differences in personnel or weather on our ability to observe cetaceans.

The increase in observed numbers of fin, humpback, minke and killer whales could be due to changes in foraging behavior (time at the surface), distribution or abundance. We lack the broadscale data necessary to put these local changes into context, but data from previous surveys by others suggest that the marine "habitats" used by the whales that we observed were typical of the species involved, and that a relatively small change in their distribution could have brought these animals into our study area. For example, fin whales have been recorded in the shallow waters $(<120 \mathrm{~m})$ of the Bering Sea Shelf between St. Paul and St. Matthew Islands (Leatherwood et al., 1983). Both Leatherwood et al. (1983) and Brueggeman et al. (1987) recorded minke whales in nearby shallow waters $(<120 \mathrm{~m})$, and Leatherwood et al. (1983) reported sightings of minke whales northeast of the Pribilofs. Likewise, most sightings of humpback whales in the Bering Sea (67\%) have been in water less than 200 m deep (Brueggeman et al., 1987), and a few sightings have been reported to the northeast of St. Paul Island (Leatherwood et al., 1983). A relatively small shift in distribution for each of these species could have resulted in an increase in the number of individuals in our study area (see Baker et al., 1992, for a discussion of local movements of humpback whales in southeastern Alaska).

Bering Sea populations may have increased in some cases. Frost et al. (1992) documented increases in killer whales in nearby Bristol Bay, and increased numbers near the Pribilofs in the 1980s may reflect a broader increase for this species in the southeastern Bering Sea. Similarly, some stocks of humpback whales that contribute individuals to summer populations in the southeastern Bering Sea are increasing (Baker et al., 1992; Braham et al., 1992). It is possible that the increases we found around the Pribilof Islands reflect increased use by this species of the southeastern Bering Sea.

Contemporaneous with the observed change in numbers of various marine mammals was an increase in the numbers of foraging short-tailed shearwaters in the vicinity of the Pribilof Islands. These birds foraged primarily on adult female Thysanoessa raschii, a species of euphausiid commonly found in shallow continental shelf waters, and less frequently on $T$. inermis, a shelf-edge species (G.L. Hunt et al., unpubl.). The three species of baleen whales that showed apparent increases near the Pribilofs were often seen in proximity to foraging flocks of shearwaters. In studies elsewhere, whales have responded to increased prey abundance by shifting their foraging distribution totake advantage of areas rich in prey (Whitehead and Carscadden, 1985; Wishner et al., 1988; Payne et al., 1990; Baker et al., 1992; Schilling et al., 1992). Fin, humpback and minke whales all take euphausiids (Baker et al., 1992; Braham et al., 1992), and it is possible that the increases in foraging shearwaters and whales were the result of euphausiids being more abundant in the 1980s than in the 1970s. However, we know of no direct measures of euphausiid abundance near the Pribilof Islands in either time period.

The period between the mid-1970s and the late 1980s was a time of major change for a number of species of marine birds and mammals at the Pribilof Islands and in the nearby southeastern Bering Sea. Sea surface temperatures rose during this period, and declines in populations (or failures in reproduction) were common for a number of species of marine birds, northern fur seals (Callorhinus ursinus), and northern sea lions (Eumetopias jubatus) (Trites, 1992; Springer, 1992; Decker et al., 1994). The local increases in numbers of whales (and shearwaters) recorded here run counter to this trend. The ultimate factor or factors responsible for these apparent population shifts are unknown.

\section{ACKNOWLEDGEMENTS}

We thank the numerous observers who contributed and recorded the observations of marine mammals on these cruises. We thank D.W. Cheng for extracting the 1975-78 marine mammal data for us from the Platforms of Opportunity Program at the National Marine Mammal Laboratory, and the captains and crews of the SS Surveyor, SS Discoverer and RV Alpha Helix. R. Russell provided aid with the statistical analysis. Figures were drawn by K. Christiansen. We thank D. DeMaster, A. York and three anonymous reviewers for comments on an earlier version of this manuscript. L. Baretta was supported by 
a Presidential Undergraduate Fellowship from the University of California Irvine; G. Hunt was supported by contracts from the OCSEAP program and by National Science Foundation Grant DPP -8521178 .

\section{REFERENCES}

BAKER, C.S., STRALEY, J.M., and PERRY, A. 1992. Population characteristics of individually identified humpback whales in southeastern Alaska: Summer and fall 1986. Fishery Bulletin 90:429-437.

BRAHAM, H.W., OLIVER, G.W., FOWLER, C., FROST, K., FAY, F., COWLES, C., SCHNEIDER, K., and CALKINS, D. 1992. Marine mammals. In: Hameedi, M.J., ed. The St. George basin environment and possible consequences of planned offshore oil and gas development. U.S. Department of Commerce, U.S. Department of the Interior, Outer Continental Shelf Environmental Assessment Program, Juneau, Alaska. 55-81.

BRUEGGEMAN, J.J., GREEN, L.A., GROTEFENDT, R.A., and CHAPMAN, D.G. 1987. Aerial surveys of endangered cetaceans and other marine mammals in the northwestern Gulf of Alaska and southeastern Bering Sea. In: NOAA/OCSEAP Environmental Assessment of the Alaskan Continental Shelf. Final Reports of Principal Investigators 61:1-124.

CONSIGLIERI, L.D., and BOUCHET, C. 1981. Marine mammal data documentation for the Platforms of Opportunity Program and Outer Continental Shelf Environmental Assessment Program. In: NOAA/OCSEAP Environmental Assessment of the Alaskan Continental Shelf. Final Reports of Principal Investigators 20:265-364.

COYLE, K.O., HUNT, G.L., Jr., DECKER, M.B., and WEINGARTNER, T.J. 1992. Murre foraging, epibenthic sound scattering and tidal advection over a shoal near St. George Island, Bering Sea. Marine Ecology Progress Series 83:1-14.

DECKER, M.B., HUNT, G.L., Jr., and BYRD, G.V., Jr. 1994. The relationship between sea-surface temperature, the abundance of juvenile Walleye-Pollock (Theragra chalcogramma), and the reproductive performance and diets of seabirds at the Pribilof Islands in the southeastern Bering Sea. Canadian Special Publication of Fisheries and Aquatic Sciences 121.

FROST, K.J., LOWRY, L.F., and BURNS, J.J. 1982. Distribution of marine mammals in the coastal zone of the Bering Sea during summer and autumn. In: NOAA/OCSEAP Environmental Assessment of the Alaskan Continental Shelf. Final Reports of Principal Investigators 26:356-561.

FROST, K.J., RUSSELL, R.B., and LOWRY, L.F. 1992. Killer whales, Orcinus orca, in the southeastern Bering Sea: Recent sightings and predation on other marine mammals. Marine Mammal Science 8:110-119.
HUNT, G.L., Jr., COYLE, K.O., HOFFMAN, S., DECKER, M.B., and FLINT, E. Unpubl. manuscript. Foraging ecology of shorttailed shearwaters near the Pribilof Islands. Available from G.L. Hunt Jr. at Department of Ecology and Evolutionary Biology, University of California, Irvine, CA 92717, U.S.A.

HUNT, G.L., Jr., EPPLEY, Z., BURGESON, B., and SQUIBB, R 1981. Reproductive ecology, foods and foraging areas of seabirds nesting on the Pribilof Islands, 1975-1979. In: NOAA/OCSEAP Environmental Assessment of the Alaskan Continental Shelf. Final Reports of Principal Investigators 12:1-257.

LEATHERWOOD, S., BOWLES, A.E., and REEVES, R.R. 1983. Aerial surveys of marine mammals in the southeastern Bering Sea. In: NOAA/OCSEAP Environmental Assessment of the Alaskan Continental Shelf. Final Reports of Principal Investigators 42:147-473.

PAYNE, P.M., WILEY, D.N., YOUNG, S.B., PITTMAN, S., CLAPHAM, P.J., and JOSSI, J.W. 1990. Recent fluctuations in the abundance of baleen whales in the southern Gulf of Maine in relation to changes in selected prey. Fishery Bulletin 88:687-696.

RICE, D.W., and WOLMAN, A.A. 1971. The life history and ecology of the gray whale (Eschrichtius robustus). American Society of Mammologists Special Publication 3:1-142.

ROHLF, F.J., and SOKAL, R.R. 1981. Statistical tables. Second edition. New York: W.H. Freeman and Company.

SCHILLING, M.R., SEIPT, I., WEINRICH, M.T., FROHOCK, S.E., KUHLBERG, A.E., and CLAPHAM, P.J. 1992. Behavior of individually-identified sei whales Balaenoptera borealis during an episodic influx into the southern Gulf of Maine in 1986. Fishery Bulletin 90:749-755.

SOWLS, A.L., HATCH, S.A., and LENSINK, C.J. 1978. Catalog of Alaskan seabird colonies. Anchorage: US. Fish and Wildlife Service. FWS/085-78/78.

SPRINGER, A.M. 1992. A review: Walleye-Pollock in the North Pacific - how much difference do they really make? Fisheries Oceanography 1:80-96.

TRITES, A.W. 1992. Northern fur seals: Why have they declined? Aquatic Mammals 18:3-18.

WHITEHEAD, H., and CARSCADDEN, J.E. 1985. Predicting inshore whale abundance-whales and capelin off the Newfoundland coast. Canadian Journal of Fisheries and Aquatic Science 42:976-981.

WILLIAMS, D.A. 1976. Improved likelihood ratio tests for complete contingency tables. Biometrika 63:33-37.

WISHNER, K., DURBIN, E., DURBIN, A., MACAULAY, M., WINN, H., and KENNY, R. 1988. Copepod patches and right whales in the Great South Channel off New England. Bulletin of Marine Science 43:825-844. 